\title{
Are High Performance Work Systems Compatible with the Extending Working Life agenda?
}

\author{
Abstract \\ Purpose - The paper examines the compatibility of two UK policy priorities - extending \\ working life (EWL) and the promotion of national economic performance through high \\ performance work systems (HPWS). \\ Design/methodology/approach - Empirical analysis has been conducted using data \\ from WERS2011 to test hypotheses on whether age moderates the link between \\ HPWP and employee well-being outcomes.
}

Findings - Development-oriented human resource strategies are found to compromise the subjective well-being of older workers relative to their younger counterparts, while some dimensions of HPWS lead to more favourable subjective well-being outcomes for older workers relative to younger ones (flexible working, performance related pay and appraisal systems).

Research limitations/implications - At older ages those still in the workforce are likely to be over-represented by happier and psychologically more robust individuals who have settled into jobs they find fulfilling, which match their personal characteristics and abilities. If so, the adverse well-being influence of development-oriented strategies may become understated, while favourable well-being outcomes for older workers may be overstated.

Practical implications - HRM strategies may need to be more age sensitive to support the EWL agenda better.

Originality/value - While many studies have examined the link between HPWS and a range of individual-level outcomes, less widely researched is whether responses vary by age, which this study addresses.

Key words: Quantitative, WERS2011, Ageing workforce, Extending Working Life, HPWS/AMO, Job Satisfaction, Subjective well-being. 


\section{Introduction}

Increasing longevity in the UK and elsewhere in western societies has long raised questions on the sustainability of state and occupational pension schemes. The issue has come into sharp focus in the aftermath of the 2008 global financial crisis, which economic fallouts from the Covid-19 pandemic are likely to give even more prominence. In the UK there has also been a government deficit reduction programmes since 2010 , which is the biggest deficit reduction ever witnessed in any advanced economy since World War II (Riley \& Chote, 2014). These factors led to significant pressures on the public finances. Over the same period, the UK has also experienced weak economic growth, with reports of widespread skills shortages and productivity flatlining (ONS, 2017; DWP, 2014; UKCES, 2014).

In response to the challenges posed by raised life expectancy and a looming pensions crisis, extending working lives (EWL) has been identified as a policy priority (DWP, 2014), which the Organisation for Economic Co-operation and Development (OECD) had recommended to member states (OECD 2005). As part of this drive, a range of measures has been introduced to facilitate and prolong employment in the UK. The measures include: the abolition of the default retirement age, the implementation of incremental increases in state pension age, and the inclusion of ageism into workplace anti-discrimination legislation (Wainwright, et al. 2018).

Alongside the EWL initiatives, there has also been a growing commitment to boost national economic performance and accelerate economic recovery. A range of human resource management (HRM) practices has been adopted to achieve higher productivity and improve organisational competitiveness (BIS, 2012; Belt and Giles, 2009; Stone, 2011). These practices, which are often termed high performance work systems (HPWS), are designed to improve organisational performance through the promotion of employee capability, commitment, and productivity (Appelbaum et al. 2000; Datta et al. 2005; Posthuma et al. 2013) though there is a lack of consensus on the structure of HPWS and the practices therein (Ramsay et al, 2000; Guest, 2002; Butler et al. 2004; Wood et al. 2012; Posthuma et al. 2013; Boxall et al. 2019).

Employee subjective well-being (Deiner 1984, 1994; Warr, 1990, 2007) (wellbeing hereinafter), which is a context-specific measure of well-being relating to one's job, has been given considerable attention in organisation studies in recent years (see, for example, Galabova \& McKie, 2013; Huang et al. 2016). Much of the literature asserts that improved worker well-being has the potential to enhance the effort, 
contribution, and productivity of the worker. Some have even established a causal link between well-being and productivity, where improved well-being at the level of an individual has been shown to improve their productivity in laboratory experiments (Oswald et al. 2015).

Importantly, employee well-being has been identified as one of the key underlying mechanisms linking HPWS to organisational- and worker-level outcomes. However, the literature examining the relationship between HPWS and worker wellbeing has generated mixed results. Broadly, two competing perspectives have been identified in this respect (see Butler et al, 2004; Ramsay et al, 2000 and Wood et al, 2012 for a discussion). The first, an 'optimistic' and 'mutual gains' perspective, suggests that HPWS promotes autonomy, empowerment, fulfilment and a sense of engagement. It increases individual commitment, motivation, well-being, and satisfaction, leading to positive performance outcomes (Appelbaum et al, 2000; Guest, 2006). The second, an 'exploitation' perspective, is informed by critical management and labour process theory (Braverman, 1974). It typifies a management-by-stress perspective whereby HPWS achieves positive performance outcomes via increased work intensification, which is often associated with stress, reduced well-being and even mental health problems (Boxall and Macky, 2014; Hughes, 2008; Lloyd and Payne, 2006).

To the extent that a 'management-by-stress' model prevails, there are implications for worker stress and anxiety, thus adverse well-being outcomes. If so, a threat may arise to the EWL agenda where older workers struggle to adjust to some of the HPWS practices workplaces adopt. This would signify tension between the dual policy aims of EWL and HPWS. The HPWS literature does not differentiate theorised impacts by age and, as noted by Truxillo et al (2014: 31), "integration of HPWS and strategic HRM literature with the ageing workforce literature is an opportunity ripe for exploration". This is imperative given the shifting capacities and orientations of older workers with the changing workplace demographics. Roberts (2006) has argued that maximising the efficiency of individual employees within the 'new capitalism' undermines traditional intergenerational relationships within the workplace with adverse implications for the welfare of older workers. There is a gap about whether the link between HPWS and well-being is moderated by age (Griffiths 2007; Kooij et al. 2013). 
Addressing this gap is vital given the changing workplace demography and the reported escalation of stress and mental health problems at work (Vickerstaff et al., 2012; HSE, 2009). Job strain at work has been identified as the most prevalent form of mental distress (Irvine, 2012) and mental health problems, including stress, are a key determinant of premature labour market exit (Rice et al., 2011; Hintsa et al., 2015). Job satisfaction is a similarly strong predictor of work performance and propensity to quit (Harrison et al., 2006). It has been suggested that poor work design and inappropriate managerial styles may be stronger determinants of early retirement than physically demanding jobs (Ferrie, 2004; Griffiths, 2007; Kloimuller et al, 1997). Given the importance of mental health for the retention of older employees, this study focuses on well-being and satisfaction outcomes and examine the impact of HPWS on workers' affective well-being (job anxiety) and job satisfaction outcomes, which have been shown to have a link with involuntary job exit or voluntary intentions to retire. The study uses Conservation of Resources (COR) theory (Hobfoll 1988; 1989) to inform the empirical analysis conducted.

\section{Theory and hypotheses}

\section{Conservation of resources (COR) theory}

Changing responses to workplace practices as individuals age are predicted by conservation of resources (COR) theory (Hobfoll, 1988; 1989). The basic principle of the theory is that individuals strive to acquire, maintain, foster, and protect resources such as health, well-being, self-esteem and family which they value centrally (Hobfoll et al. 2018; Hobfoll, 1988; 1989). Importantly, "COR theory follows an understanding that cognitions have an evolutionary-based built-in and powerful bias to overweight resource loss and underweight resource gain" (Hobfoll et al. 2018: 104). The theory posits that stress occurs (a) when key resources are faced with the threat of loss, (b) when such resources are lost, or (c) when a significant effort to acquire key resources becomes unsuccessful (Hobfoll et al. 2018)

As individuals age their resources tend to be depleted or threatened. On the other hand, the changing nature of work that is driven by globalisation, technological change, business pressures and growing uncertainties necessitate agility on the part of organisations and adaptability of their employee. As Boxall et al. (2019: 9) note, "firms that wish to adopt a more flexible form of work design require workers who can 
handle the unexpected by developing a capability for learning." Older workers may be less well placed to cope with the changing demands and new challenges at work (Treadway et al., 2005; Wright \& Hobfall, 2004). Depending on age, employees may thus respond differently to the same work circumstances and context. In theorising age moderated relationships between HPWS and well-being outcomes, the critical criteria are therefore the extent to which the goals of specific HPWSs are aligned with the goals and priorities of older workers, and the extent to which the practices facilitate or block the processes of adaptation.

\section{HPWS}

As noted earlier, there is a lack of consensus over the definition and measurement of HPWS. In a recent review, Boxall et al. (2019: 3) noted that "reviews and studies of HPWPs have regularly observed that little consensus exists among researchers regarding the specific practices to be included in the configuration of high performance human resource practices." Broadly, however, the aim of HPWS is to maximise discretionary effort by means of good quality jobs, incentives and employee involvement (in jobs and organisations); and to promote the development and use of skills to achieve high levels of performance (Belt and Giles, 2009; Stone et al, 2012; UKCES, 2009). In most early applications the focus was on the positive influence of HPWS on organisation-level outcomes (Huang et al. 2016; Boxall \& Macky, 2009; Sun et al., 2007; Wright et al., 2005). In majority of later applications centred on employeelevel outcome such as well-being, HPWS invokes 3 key dimensions of HR practices following Appelbaum et al. (2000). Appelbaum highlighted how HRM practices aimed at improving employees' abilities (A), motivation (M) and opportunity to contribute $(\mathrm{O})$ - i.e. an approach based on the AMO model - could boost both worker performance and well-being (Appelbaum et al. 2000; Wright et al, 2003; Jiang et al, 2012; Guest 2017). Given the well-being focus of this study, which is individual-level outcome, we adopt the AMO framework of categorising HR practices in the theorising that follows, where we consider distinct sub-practices in each case.

\section{HPWS and older worker well-being}

\section{Ability}


Research has highlighted the changing demands of work and the need for constant adjustment through retraining and skills updating, which give rise to high pressure workplaces that can be stressful for older workers in particular (BarnesFarrell, 2005; Alley \& Crimmins, 2007; Shultz et al., 2010; Schultz and Wang 2011). Older workers are found to focus less on promotion and advancement (including training) and given their shifting goals, developmental HR practices become less appropriate for them (Kooij et al., 2011; Freund, 2006). 'High performance' expectations of continual development may therefore exert a negative influence on their well-being by disrupting adaptations that might otherwise be deployed at later career stages. Therefore, we hypothesise:

H1: Changing demands of work and associated policies/practices aimed at employee development, lead to high-pressure working environments adversely impacting older workers' well-being and job satisfaction.

\section{Motivation}

Performance related pay (PRP) can engender a sense that rewards are a fair reflection of effort, the potential impact of PRP on well-being may also work through mechanisms of 'recognition'. As noted in a study by the Work Foundation (2005) the linking of pay to effort and productivity, rather than being a source of stress and control, can be interpreted as a welcome incentive, which recognises and rewards efforts. Insofar as recognition is highly valued among older workers, as an instrument of appreciation, PRP may have positive age moderating effects. Where PRP may derive effort through the processes of 'bureaucratic control' (Edwards, 1979; McGovern et al. 2007:163), it may act as a stressor. However, pay and other extrinsic job characteristics are deprioritised at older age (Bown-Wilson and Parry, 2013; Kanfer \& Ackerman, 2004; $\mathrm{Ng}$ and Feldman, 2012; Ng and Feldman, 2008). Moreover, it is suggested that older age can 'buffer' against potential work stressors due to a greater range of coping resources (Mauno et al., 2013). Overall, therefore:

H2: PRP is positively associated with older workers' well-being and job satisfaction. 
Shacklock and Brunetto (2011) have shown that flexibility of working arrangements contributes to older workers' intentions to remain in paid employment. This is because flexibility of working is likely to enable older workers to juggle competing demands such as caring responsibility and dealing with one's own poor health, as well as inducing discretionary effort as an act of 'social exchange'.

H3: Flexible working is positively associated with older workers' well-being and satisfaction outcomes.

Appraisal systems may seek to secure higher performance through more direct motivating systems of control. Edwards (1979) noted that employees get induced to expend greater effort through methods of 'bureaucratic control'; while McGovern et al. (2007:163) stated 'there is always an implicit resistance' and 'contestation' associated with systems of control and incentive. Appraisals, which are often a tool of performance management, may give rise to reduced well-being and satisfaction in general. For older workers, however, appraisals may help provide opportunities to influence targets and objectives; discuss general work issues; or 'provide a means by which they can individually transmit some influence up' (McGovern et al, 2007: 164). This ability to influence may facilitate processes of adaptation at older ages given the Shifting Preferences argument where, as noted earlier, the need for recognition increases with age while extrinsic aspects of work become less important.

H4: Appraisal systems, both as a signal of 'recognition' and to exert influence on work processes and objectives, impacts older workers' well-being and job satisfaction positively.

\section{Opportunity}

Drawing on Wood \& de Menezes (2011)'s conceptualisation of HPWS, which emphasises the importance of workplace 'involvement', both role involvement and organisation involvement practices can be differentiated within the 'opportunity' 
cluster. Role involvement (including teamwork, job autonomy and variety) is associated with more fulfilling and interesting work. These are job qualities to which employees of all age aspire to (Warr, 2007) and the literature consistently finds positive well-being outcomes in relation to enriched jobs (Humphrey et al, 2007; Wood \& de Menezes, 2011). Components of role involvement are key means whereby older workers can effectively adapt the way work is performed. As noted by Truxillo et al. (2013) and Kanfer \& Ackerman (2004), at young age employees need more support and direction as they develop job skills and experience, which older workers may gainfully provide. Thus:

H5: Role involvement opportunities, including job autonomy and teamwork, positively impact older workers' well-being and job satisfaction.

Opportunity to exert discretionary effort is also promoted by means of 'organisational involvement' through enhanced communication strategies (Wood \& de Menezes, 2011). Heightened communication channels are associated with greater social interaction and therefore likely to promote a sense of being 'socially embedded' within an organisation. This dimension of HPWS may also stimulate a sense of belonging by signalling recognition, respect and appreciation of staff contributions job qualities which have been found to be of particular value to older workers (Armstrong-Stassen and Schlosser, 2011; Deller et al, 2009; Truxillo and Fraccaroli, 2013). The existence of practices that encourage employees to contribute ideas, which influence work practices and culture, are likely to promote adaptations, enable modifications of working environment to offset declines and engender feeling valued. It is hypothesised that organisational involvement is particularly consistent with older workers' preferences and may promote age sensitive workplace adaptations, therefore:

H6: Organisational involvement practices, including top-down communication and engagement, enhance older workers' well-being and job satisfaction. 


\section{Methods}

\section{Data}

In this study HPWS and several other workplace characteristics are treated as organisation-level variables, while employee well-being and other demographic and human capital characteristics of workers including age are treated as employee-level variables. The data come from the 2011 Workplace Employment Relations Survey (WERS2011), a nationally representative matched employer-employee data of workplaces in Britain with five or more employees, in both private and public sectors, and including all industrial sectors (except those engaged in primary activities and private households with domestic staff). Responses were solicited at each workplace from managers with day-to-day responsibility for employment relations and from employees through a self-completion questionnaire (Van Wanrooy et al. 2013).

It is by combining the management and employee data collected for each sample of workplaces that the linked employer-employee data are generated. The study sample consists of 19,939 employees in 1,628 establishments. These were achieved after eliminating missing values in the outcome or control variables used in the multivariate analyses.

\section{Outcome measures}

Employee responses on questions relating to 'job anxiety' and 'job satisfaction', have been used to yield the well-being outcomes. The survey used Warr's (1990) conceptualisation of employees' job-related well-being, monitoring how much of the time their job made employees feel: (i) 'tense' (ii) 'depressed' (iii) 'worried', (iv) 'gloomy', (v) 'uneasy', and (vi) 'miserable' over a period of a few weeks preceding the interview. The responses are captured on a five-point scale from 'all of the time' to 'never'. The six items capture two sets of emotions: work-related anxiety (tense, worried and uneasy) which is a function of high workload and work-related depression (gloomy, depressed, and miserable) (see Warr, 1990, 2007). Additionally, three responses that are thought to reflect work related anxiety and stress, viz., whether employees: (i) 'work very hard' to complete their job, (ii) 'don't have enough time to get their work done' and (iii) 'don't have enough time off work' have been used. 
Secondly, WERS2011 also elicited employees' responses using a five-point scale from 'very satisfied' to 'very dissatisfied' on the following aspects of their job: (i) 'the sense of achievement from work'; (ii) 'the scope for using own initiative'; (iii) 'the amount of influence over the job'; (iv) 'the training received'; (v) 'the opportunity to develop your skills in your job', (vi) 'the amount of pay'; (vii) 'job security'; (viii) 'the work itself', and (ix) 'involvement in decision making'. To establish whether the outcome responses signify distinct well-being measures or if they needed to be combined in some way, factor analysis was conducted on the 18-item well-being and job satisfaction measures. The analysis identified two principal factors with Eigenvalues above 1 (7.43791 and 2.46163), which account for $92.4 \%$ of the total variance (see accompanying Table $1 \mathrm{~A}$ in the Appendix). The rotated factor loadings indicated that responses given to the nine job satisfaction related questions form a single factor (Factor 1), defined as 'job satisfaction' while responses to the 'job anxiety' questions together form a second unique/single factor (Factor 2), defined as 'wellbeing' (see accompanying Table 1B in the Appendix). The empirical analysis therefore relies on these two outcome measures.

The top panel of Table 1 reports descriptive statistics on the two outcome measures. The raw comparisons reveal that older workers experience higher levels of well-being (i.e. lower levels of job anxiety) and higher levels of job satisfaction than younger workers, the raw differences being significantly different from zero.

[Table 1 about here]

\section{HPWS and other control variables}

A comprehensive range of HPWS measures are available from WERS2011 covering the key bundles of HPWS policies and practices widely used in the literature. We initially disaggregate these policies and practices into the three components of Ability, Motivation and Opportunity before conducting factor analysis to confirm if the disaggregated components were supported empirically. The factor analysis on the 3items aimed at employee development identified 1 factor with Eigenvalue above 1 (3.9221), yielding the 'Ability' measure. Similarly, factor analysis on the 13-item policies and practices aimed at influencing motivation and effort identified 3 factors with Eigenvalues above 1 (3.9113, 2.5662 and 1.97093), corresponding to 'incentive/rewards', 'appraisal and 'flexible working', which constitute the 'Motivation' 
measure. Finally, factor analysis on the 19-item policies and practice measures aimed at creating 'Opportunity' identified 4 factors with Eigenvalues above 1 (3.51892, 2. $93421,2.3987$ and 1.16098), corresponding to 'job autonomy', 'teamwork', 'top-down communication' and 'employee engagement'. Constituent items and question wording relating to each of these 8 bundles of practices are presented in Table 2 .

[Table 2 about here]

\section{Other controls}

In keeping with previous studies discussed above, and government EWL policy which identifies age 50 as a key marker beyond which participation rates start to decline, older workers are defined as those aged $50+$. They constitute $30.4 \%$ of the retained sample. Until recently, 50 has also been the age from which access to occupational pensions has been permitted. There is extensive literature highlighting the moderating effect of age, where job satisfaction increases as people age (see Riza et al. 2018 for a recent study) based on chronological age as used in this study.

The WERS surveys monitored a broad range of other employee and employer characteristics. On employees, these included a battery of demographic, human capital and job characteristics such as gender, educational attainment, disability status, marital status, pay, hours, contractual type, occupational group, seniority and organisational tenure, which are all controlled for in the models estimated. On workplaces, the models control for establishment age, size, ownership type and industry. Age-based stereotypes and discrimination, including from line managers, may act as stressors negatively affecting job satisfaction and psychological well-being (see Avidor et al. 2017; Schmitt et al. 2014; Cunningham et al. 2004) while organisational climate for age inclusion is found to yield higher job satisfaction outcomes (Bilinska et al. 2016). Taking these into account the study uses two additional controls that capture reported grievances of "discrimination" and "unfair treatment by line manager or supervisor" at the study organisations. In addition, the study controls for organisational-level age diversity, which is measured as $1-\mathrm{H}$ (where $\mathrm{H}$ is the Herfindahl Index). This may be important given that organisations with a high degree of age diversity may be more inclusive. Also, some of the AMO measures described in Table 2 are relevant to the majority $(80 \%$ in the case of appraisal 
schemes) of employees while others may not be so. Table 5 in the Appendix provides summary statistics on the additional controls used.

\section{Empirical model}

The analytical approach adopted is informed by the structure of the WERS data, which has employees nested within workplaces. The two-level model deployed is given by:

$$
y_{i j}=\alpha+\boldsymbol{\beta}^{\prime} \boldsymbol{x}_{i j}+\boldsymbol{\delta}^{\prime} \boldsymbol{w}_{j}+\mu_{j}+\varepsilon_{i j} ; \quad i=1, \ldots, N \text { and } j=1, \ldots, M
$$

where $y$ represents each of the two outcomes - well-being and satisfaction for employee $i$ in workplace $j$. The vector of employee characteristics is represented by $\boldsymbol{x}$. The vector of workplace characteristics, which also includes the bundles of HPWS measures is represented by $w$. The model assumes that the workplace-level unobserved characteristics $\mu_{j}$ and the idiosyncratic error term $\varepsilon_{i j}$ are distributed as $\mu_{j} \sim N\left(0, \sigma_{\mu}^{2}\right)$ and $\varepsilon_{i j} \sim N\left(0, \sigma_{e}^{2}\right)$, respectively. The model is estimated using the randomintercept model, which allows partitioning the unexplained variation in our outcomes into workplace-level variance, which represent unobserved workplace heterogeneity, and a residual variance term.

The regression analysis involves three different specifications. The first specification examines the independent link between the well-being outcomes and employee and employer characteristics; including whether the employee is an older worker (HPWS practices are not included in these models). The second specification includes the 8 bundles of HPWS identified by the factor analysis, while the third specification includes interaction terms of older worker status and each of the bundles additionally. Estimation is conducted using the STATA software (StataCorp. 2019).

\section{Findings}

Table 3 reports a portion of the estimation results focusing on the key controls of old age on its own (columns 1 and 2) as well as with HPWS measures (columns 3 and 4 ) and the interactions of the two (columns 5 and 6 ). The estimated age-specific coefficients for the full sample (row 1) show that compared with their younger counterparts, the $50+$ experienced higher levels of job satisfaction and higher levels 
of well-being (i.e. lower levels of job-related anxiety). These findings are consistent with previous research.

The coefficients of the HPWS bundles (columns 3 to 4 ) indicate, firstly, that practices designed to promote 'ability' significantly reduced well-being but were not associated with satisfaction. Notably, the coefficient of the interaction terms of older worker and employee development reveals that the well-being of older workers is negatively affected by practices designed to promote 'ability'. Therefore, Hypothesis 1 is accepted in relation to well-being.

In relation to 'motivation' practices, no significant relationships were found for flexible working and incentive pay schemes for the full sample while appraisal systems were found to have a negative job satisfaction effect (columns 3 and 4). On the other hand, the estimated interaction terms between older worker status and each of the 'motivation' practices suggest that for older workers flexible working, appraisal systems and incentive pay schemes enhance well-being, even though only weakly in the case of appraisal systems. This means that Hypotheses 2, Hypotheses 3 and Hypothesis 4 are all confirmed in relation to older workers' well-being but not their satisfaction.

Practices which promote 'opportunity' through teamwork is found to be weakly significant with well-being while autonomy, top-down communication and employee engagement are all found to be significantly linked with job satisfaction, the latter negatively. However, none of the coefficients from the interactions of $50+$ and each of the four 'opportunity' sub-bundles is found to be statistically significant. Hence, Hypothesis 5 is rejected.

Opportunity through organisational involvement practices were divided into 2 bundles - top down communication and employee engagement. For the full sample, these bundles appear to be working in opposite directions. Different types of organisational involvement therefore appear to vary in their impacts. Neither was significantly associated with well-being, but top down communication was significantly positively associated with satisfaction while employee engagement is found to be negatively linked with satisfaction for the full sample albeit only weakly. On the other hand, the coefficients from the interaction terms of old age and the two bundles of 'opportunity' reveal no statistically significant age moderation. Thus, Hypothesis 6 is rejected. 
[Table 3 about here]

\section{Discussion}

This study attempted to contribute to the growing evidence base by highlighting which HPWS policies and practices may have favourable age moderating effects and which practices may pose a threat to satisfaction and well-being (and therefore to the EWL agenda). Within the AMO framework, age moderated impacts were evident for the 'ability' and 'motivation' policies and practices, but moderating effects did not extend to the bundles of practices associated with 'opportunity'.

\section{Ability}

Addressing initially the 'ability' HPWS bundle, the negative age moderating effects of development-oriented practices on well-being reflects a move away from the goals of advancement and development later in life. This evidence is consistent with predictions of COR theory, where the threat of loss or actual loss of key resources can prove stressful for older workers (Hobfoll 1988, 1989). As their time-tested ways of doing things get challenged by workplaces' need for continual adjustment, it may not be entirely surprising that older workers' well-being get compromised by developmentoriented workplace policies and practices. This finding is also consistent with previous findings in the literature (Kooij et al, 2011; Freund, 2006, for example), which suggested that older workers focus less on promotion and advancement (including training) and that developmental expectations may become less appropriate for older workers given their shifting goals. Several other studies (Barnes-Farrell, 2005; Shultz et al, 2010; Alley \& Crimmins, 2007) have also highlighted that the demand for continuous work adjustment led to high-pressure workplaces for older workers, adversely impacting their well-being. Having said that, it may be worth undertaking occupation-based sensitivity analysis. We do control for occupation in our regressions. However, the group size of older workers in the estimation sample does not permit further disaggregation of older workers by occupation. This may be one area that future research may usefully contribute to.

\section{Motivation}


Motivation exhibited age moderating effects as hypothesised, with a significant positive link between older workers' well-being and each of the three motivation bundles of 'flexible work', 'appraisal scheme' and 'incentive pay'. On the other hand, none of the bundles was found to have significant influence on older workers' job satisfaction. Extrinsic rewards become deprioritised at older ages (Bown-Wilson and Parry, 2013; Kanfer \& Ackerman, 2004; Ng and Feldman, 2010; Ng and Feldman, 2008), which weakens the scope for PRP to motivate effort. However, the potential impact of PRP on older worker well-being is likely to work through mechanisms of 'recognition'. Recognition is highly valued among older workers and therefore, as an instrument of appreciation, PRP is consistent with age related priorities. Linking pay to effort and productivity has a recognition element, which older workers appreciate more than their younger counterparts (Work Foundation 2005). It is also pointed that older workers are generally better poised and can 'buffer' against potential work stressors arising from PRP, given a greater range of coping resources they have (Mauno et al., 2013). PRP's insignificant link with job satisfaction may not be entirely inconsistent with older workers' de-prioritisation of extrinsic rewards.

The positive age moderating influence of appraisal on older workers' well-being we found is as hypothesised. Appraisal schemes do offer older workers the scope for facilitating their influence and the possibility for upward communication as highlighted in McGovern et al. (2007). As such they may promote the self-esteem of older workers enhancing their well-being. It is worth pointing, however, that the result found provides only a weak evidence in this respect. Also, we do not find age moderating effect of appraisal schemes vis-à-vis older workers' job satisfaction. Therefore, the evidence we have is weak at best, and caution may be needed in interpreting the findings.

As COR theory stipulates (Hobfoll 1988; 1989; Treadway et al., 2005; Wright and Hobfall, 2004), the ageing process depletes older workers' resources making flexible working particularly valuable for them. The positive age moderating effect of flexible working we found for older workers is therefore in line with predictions of the COR theory. This is also supported by previous empirical findings, which showed that flexible working tends to encourage older workers to remain in paid employment (Shacklock and Brunetto 2011). Other research has shown that with age employees increasingly value opportunities for social interaction, generativity and a sense of being 'socially embedded' within an organization (Mor-Barak, 1995; Deller et al, 2009; Truxillo and Fraccaroli, 2013). Employers may have to weigh benefit of spatiotemporal 
flexibility against such possible adverse outcomes. Safeguarding older workers' wellbeing by addressing any unintended consequences associated with some forms of flexibility in work arrangements is therefore recommended.

\section{Opportunity}

In relation to the 'opportunity' bundles of practice, we do not find any age moderating effect on older workers well-being and job satisfaction contrary to expectations. This is despite results from the models excluding age interaction effects being broadly as expected, where teamwork is found to increase well-being (albeit weakly) while autonomy and top-down communication are found to increase satisfaction significantly. Older workers were expected to experience higher levels of well-being and/or satisfaction in the presence of 'opportunities' for discretionary effort compared with younger workers. However, it is worth emphasising that while job autonomy, teamwork and being kept informed may facilitate the processes of adaptation among older workers, they are essentially job characteristics favoured by all workers regardless of age (Warr, 2007; Humphrey et al, 2007; Wood \& de Menezes, 2011). This may explain the lack of any age moderating effects related to the 'opportunities' bundle.

Overall, therefore, older workers cannot be differentiated from younger workers in their responses to the 'opportunity' practices both in terms of well-being and job satisfaction. There appears to be limited evidence that they respond more favourably than younger workers to the 'motivation' high performance practices of flexible working, incentive payments and appraisal systems (albeit only weakly) though only in terms of well-being. With weak evidence of negative age moderating effects, the agenda of EWL does not at least appear, prima facie, to be against the HPWS drive. As expected, however, development-oriented strategies are found to have a significant negative age moderating effect, with implications for the management of an ageing workforce. These appear to reflect the challenges older workers face due to changing demands of work, including digitalisation and technological change, which require continuous adaptations. Cultures of continuous improvement and intensive developmental initiatives appear to be in tension with the priorities of older workers. This is very much in line with the COR theory and its core principle that "resource loss is disproportionately more salient than resource gain" (Hobfoll et al. 2018: 105). Loss of personal resources, which include skills and accumulated knowledge, that 
accompany the changing demands of work may weigh more heavily on older workers than the young.

The evidence relating to development expectations is also important as later career training opportunities are key concerns among policymakers who emphasise the need for lifelong learning to prevent skills obsolescence despite the evidence that participation in training/learning declines with age. The reduction in well-being associated with training and continual development seems to suggest that these downward trends do not simply reflect employer age discrimination in the provision of training opportunities but also an increased reluctance to participate at older ages as different priorities emerge. A reconsideration of how and in what format development opportunities are presented to workers is therefore warranted. In this regard, the availability of supportive work organisations and HR policies may be imperative, as highlighted in Hobfoll et al. (2018) "personal resources are likely to emerge from nurturing or supportive social conditions, these personal resources are likely to be related to having supportive families and supportive work organizations" p. 107. This may be particularly important where lean production is involved. As Boxall et al. (2019) noted, training and continual development (upskilling) may increase work intensity in this case. If so, this may not only adversely impact older workers' well-being, but the level of interdependence in this type of production may also make it difficult to insulate them. By way of recommendation, therefore, development-oriented initiatives may have to be more sensitive towards older workers. Line managers may need to be conscious of such sensitivities and be prepared, including through tailored training for line managers, to address the threats older workers face from the need for continual development and re-training.

\section{Limitations and future research}

This study attempted to contributes to the literature by highlighting the role played by age in moderating the well-being and job satisfaction influences of HPWS, which the existing literature has not explored sufficiently as Truxillo et al (2014) noted. We used disaggregated HPWS/AMO bundles based on factor analysis. However, some of the disaggregated bundles (e.g. those relating to Opportunity) appear to be working in opposite directions. This suggests different types of organisational involvements having varying effects on wellbeing as discussed in the results section. 
Future research may confirm the value of empirically disaggregated HPWS/AMO bundles. As we highlighted earlier, future research may also usefully contribute to this discourse by studying if the age moderated link found may vary by the occupational status of older workers, perhaps also by incorporating eudaimonic dimensions of wellbeing (see, for example, Brunetto et al., 2011), which captures the extent to which work tasks may be consistent with their values.

\section{Conclusion}

The paper examined the compatibility of two UK policy priorities - extending working life and the promotion of national economic performance by means of high performance work systems (HPWS). The demography of the UK population has been changing, longevity putting pressures on the public finances and threatening a pensions crisis. This has prompted the policy response of extending working lives $(E W L)$. At the same time, there has also been a growing commitment to boosting national economic performance and promoting economic recovery in the aftermath of the 2008 financial crisis in particular. This has led to the policy of deploying a range of human resource management policies and practices, which are thought to promote productivity and improve organisational competitiveness. These policy drives are set to gather pace as the economic fallout from the Covid-19 pandemic bites.

EWL would be expected to make the average age of workers in a typical workplace higher, while HPWS would generally be expected to result in changing demands of work through 'continuous adjustment' in workplaces. The need for continuous adjustments is thought to leave workplaces relatively high-pressured environment. This study examined the compatibility of the two policies of EWL and boosting economic activity via HPWS as these relate to the subjective well-being of older workers. For advocates of HPWS, higher productivity is achieved by means of enhanced employee involvement, commitment and, therefore, discretionary effort. If, as predicted by some previous studies, capacities, work-related motives, and expectations shift with age leading to a reduced willingness or ability to cope under intensified working conditions, then the EWL and HPWS policy agendas may well come into conflict.

Findings from this study indicate reduced well-being and lower job satisfaction being associated with some aspects of HPWS, suggesting pressurised working 
conditions. They also highlight the need for disaggregation of HPWS, given that different bundles exhibited quite diverse effects on the well-being and satisfaction outcomes studied. Differentiating HPWS bundles also permits a more nuanced and age-sensitive understanding of how different practices play out in the workplace.

Consistent with previous research, older workers were found to experience higher job satisfaction and higher well-being than younger ones overall, controlling for a broad range of individual and workplace level characteristics. In the presence of 8 empirically based HPWS bundles, age differences in well-being and satisfaction were discernible, however. Many, but not all, were in the directions hypothesised with reference to age-related shifts in work-related preferences. A growing body of empirical evidence has identified older workers as resilient and capable of adapting to their changing cognitive and physical abilities, if the right supportive workplace circumstances are in place. Putting in place supportive HPWS may yield better wellbeing outcomes for older workers encouraging them to continue working. If so, the policy priorities of EWL and the promotion of national economic performance through HPWS can be compatible.

\section{Acknowledgements:}

The author acknowledges the Department of Business, Innovation and Skills, the Economic and Social Research Council, the Advisory, Conciliation and Arbitration Service and the National Institute of Economic and Social Research as the originators of the 2011 Workplace Employee Relations Survey data, and the Data Archive at the University of Essex as the distributor of the data.

\section{Funding:}

The research was supported by funding from the ESRC (ES/L002884/1). The views are the author's own and do not necessarily reflect those of the ESRC. 


\section{References}

Alley, D. and Crimmins, E. (2007) The demography of aging and work. In K. S. Shultz and G. A. Adams (Eds.), Aging and work in the 21st century (pp. 7-23). New York, NY: Psychology Press.

Appelbaum E, Bailey T, Berg P. and Kalleberg AL (2000) Manufacturing Advantage: Why High Performance Work Systems Pay Off. Ithaca NY: Cornell University Press.

Armstrong-Stassen, M, and Schlosser F. (2011) Perceived Organizational Membership and the Retention of Older Workers, Journal of Organizational Behavior, 32: 319-344.

Avidor, S., Ayalon, L., Palgi, Y. and Bodner, E. (2017) Longitudinal associations between perceived age discrimination and subjective well-being: variations by age and subjective life expectancy, Aging \& Mental Health, 21: 761-765.

Barnes-Farrell, J.L (2005). Older workers. In J. Barling, E. K. Kelloway, and M. Frone (Eds.), Handbook of work stress (pp. 431-454). Thousand Oaks, CA: Sage.

Belt V and Giles L (2009) High performance working: a synthesis of the literature. London: UKCES

Bilinska, P., Wegge, J. \& Kliegel, M. (2016). Caring for the elderly but not for one's own old employees? Organizational age climate, age stereotypes, and turnover intentions in young and old nurses, Journal of Personnel Psychology, 15 (3): 95-105.

BIS (2012) Promoting High Performance Working. London: HMSO

Bown-Wilson, D. and Parry, E. (2013) Career progression in older managers, Employee Relations, 35 (3): 309 - 321.

Boxall, P., \& Macky, K. (2009). Research and theory on high-performance work systems: progressing the high-involvement stream. Human Resource Management Journal, 19(1), 3-23.

Boxall, P., Huo, ML., Macky, K. \& Winterton, J. (2019). High-Involvement Work Processes and Systems: A Review of Theory, Distribution, Outcomes And Tensions. Research in Personnel and Human Resources Management, 37: 152. 
Braverman, H. (1974), Labor and Monopoly Capital: The Degradation of Work in the Twentieth Century, Monthly Review Press, New York, and London.

Brunetto, Y., Farr-Wharton, R. \& Shacklock, K. (2011) Using the Harvard HRM model to conceptualise the impact of changes to supervision upon HRM outcomes for different types of Australian public sector employees, The International Journal of Human Resource Management, 22 (3), 553-573.

Butler P, Felstead A, Unwin L and Walters S (2004) High Performance Management: A Literature Review. Learning as Work Research Paper 1, Centre for Labour Market Studies, University of Leicester, Leicester.

Cunningham, I., James, P. \& Dibben, P. (2004). Bridging the gap between rhetoric and reality: Line managers and the protection of job security for ill workers in the modern workplace, British Journal of Management, 15: 273-290.

Datta, D., Guthrie, J. \& Wright, P. (2005). Human Resource Management And Labor Productivity: Does Industry Matter? Academy of Management Journal, 48 (1): 135-145.

Deiner, E (1984) Subjective well-being. Psychological Bulletin, 95, 542-575.

Deiner, E (1994) Assessing subjective well-being: Progress and opportunities. Social Indicators Research, 31, 103-157.

Deller J, Liedtke P and Maxin L (2009) Old age security and silver workers: an empirical survey identifies challenges for companies and societies. The Geneva Papers, 34: 137-157

DWP (2014) Fuller Working Lives: A Framework for Action. London: HMSO

Edwards R (1979) Contested Terrain: The Transformation of the Workforce in the Twentieth Century. New York: Basic Books.

Ferrie, J. (2004) Work Stress and Health: The Whitehall II Study. London: Cabinet Office.

Freund AM (2006) Differential motivational consequences of goal focus in younger and older adults, Psychology and Aging, 21 (2): 240-252.

Galabova, L. and McKie, L. (2013) 'The five fingers of my hand': Human capital and well-being in SMEs. Personnel Review, 42(6): 662-683.

Griffiths A (2007), Healthy work for older workers: work design and management factors, in Loretto, W., Vickerstaff, S. and White, P. (eds), The future for older workers: New perspectives, Bristol: The Policy Press. 
Guest D (2002) Human resource management, corporate performance and employee wellbeing: building the worker into HRM, British J. of Industrial Relations, 44 (3): 335-338

Guest D. (2006) High performance working: HRM and performance. In Porter S and Campbell M (eds.) Skills and Economic Performance. London: Caspian, 173195.

Guest, D. (2017). Human Resource Management and employee well-being: towards a new analytical framework. Human Resource Management Journal, 27(1), 2238.

Harrison DA, Newman DA and Roth PL (2006) How important are job attitudes? Metaanalytical comparisons of integrative behavioral outcomes and time sequences, Academy of Management Journal 45(2): 305-325.

Hintsa, T., Kouvonen. A., McCann, M., Jokela, M., Elovainio, M. and Demakakos, P. (2015), Higher effort-reward imbalance and lower job control predict exit from the labour market at the age of 61 years or younger: Evidence from the English Longitudinal Study of Ageing, Journal of Epidemiology and Community Health 69: 543-549.

Hobfoll, S. (1988). The Ecology of Stress. Washington, DC: Hemisphere

Hobfoll, S. (1989). Conservation of resources: a new attempt at conceptualizing stress. Am. Psychol. 44(3):513-24.

Hobfoll, S., Halbesleben, J., Neveu, JP \& Westman, M. (2018). Conservation of Resources in the Organizational Context: The Reality of Resources and Their Consequeences. Annu. Rev. of Organ. Psychol. \& Organ. Behav., 5: 103-128. HSE (2009), Health and Safety Statistics 2008/09. HSE Books, Sudbury.

Huang, LC., Ahlstrom, D., Lee, A., Chen, SY. \& Hsieh, MJ. (2016). High Performance Work Systems, employee well-being, and job involvement: an empirical study. Personnel Review, 45(2), 296-314

Hughes, J. (2008) The high performance work paradigm: A review and evaluation, Research Paper No 16, March, Cardiff School of Social Sciences, Cardiff University, Cardiff.

Humphrey SE, Nahrgang JD and Morgeson FP (2007) Integrating motivational, social, and contextual work design features: A meta-analytic summary and theoretical 
extension of the work design literature, Journal of Applied Psychology, 92: 1332-1356.

Irvine A (2012) Common mental health problems and work. In Vickerstaff, S; Phillipson, C and Wilkie, R (2012) Work Health and Wellbeing. Bristol: Policy Press

Jiang, K., Lepak, D., Han, K., Hong, Y., Kim, A. and Winkler, A.L. (2012). 'Clarifying the construct of human resource systems: relating human resource management to employee performance', Human Resource Management Review, 22 (2): 73-85

Kanfer, R. and Ackerman, P.L. (2004), "Aging, adult development, and work motivation", Academy of Management Review, Vol. 29(3): 440-458.

Kloimuller, I., Karazman, R. \& Geissler, H. (1997) How do stress impacts change with ageing in the profession of bus drivers? In Sepala, T., Luopajarvi, C-H. \& Matilla, M. (eds.), From Experience to Innovation: Vol. V, Proceedings of the 13th triennial congress, International Ergonomics Association. Helsinki:

Finnish Institute of Occupational Health.

Kooij D, De Lange AH, Kanfer R and Dikkers JSE (2011) Age and Work-Related Motives: Results of a Meta-Analysis, Journal of Organizational Behavior, 32: 197-225.

Kooij D, Guest D, Clinton M, Knight T, Jansen P, and Dikkers J (2013) How the Impact of HR Practices on Employee Well-Being and Performance changes With Age, Human Resource Management Journal, 23: 18-35.

Lloyd C and Payne J (2006) Goodbye to all that? a critical re-evaluation of the role of the high performance work organization within the UK skills debate, Work, Employment and Society, 20(1): 151-165

Mauno, S., Ruokolainen, M. \& Kinnunen, U. (2013) Does aging make employees more resilient to job stress? Age as a moderator in the job stressor-well-being relationship in three Finnish occupational samples, Aging \&Mental Health, 17(4): 411-422

McGovern P, Hill S, Mills C and White M (2007) Market, Class, and Employment. Oxford: Oxford University Press. 
Mor-Barak ME (1995) The meaning of work for older adults, International_Journal of Aging and Human Development, 41(4): 325-344.

Ng, T.W.H. and Feldman, D.C. (2008) The Relationship of Age to Ten Dimensions of Job Performance, Journal of Applied Psychology, 93(2):392-423.

Ng, T.W.H. and Feldman, D.C. (2012) Evaluating Six Common Stereotypes about Older Workers with Meta-Analytical Data, Personnel Psychology, 65(4): 821. 58.

OECD (2005), Ageing and Employment Policies: Synthesis Report, Paris: OECD.

OECD (2013) OECD Employment Outlook 2013. OECD publishing.

ONS (2017), Labour Productivity: April to June 2017, Office for National Statistics Statistical Bulletin, 6 October 2017 release, London.

Oswald, A., Proto, E. and Sgroi,. D. (2015) Happiness and productivity. Journal of Labor Economics 33(4): 789-822.

Posthuma, R., Campion, M., Masimova, M. \& Campion, M. (2013). A High Performance Work Practices Taxonomy: Integrating the Literature and Directing Future Research. Journal of Management, 39 (5): 1184-1220.

Ramsay, H., Scholarios, D. and Harley, B. (2000) Employees and High-Performance Work Systems: Testing inside the Black Box, British Journal of Industrial Relations 38 (4): 501-531

Rice, N., Lang, I., Henley, W., and Melzer, D. (2011) Common health predictors of early retirement: Findings from ELSA. Age Ageing 2011, 40(1): 54-61.

Riley, J. \& Chote, R. (2014). Crisis and consolidation in the public finances. Office for Budget Responsibility, Working Paper No. 7, London.

Riza, S., Ganzach, Y. and Liu, Y. (2018), Time and Job Satisfaction: A Longitudinal Study of the Differential Roles of Age and Tenure, Journal of Management, 44 (7), 2558-2579.

Roberts, I. (2006) Taking age out of the workplace: putting older workers back in? Work, Employment and Society, 20(1): 67-86.

Schmitt, T., Branscombe, R., Postmes, T. \& Garcia, A. (2014). The consequences of perceived discrimination for psychological well-being: a meta-analytic review, Psychological bulletin, 140 (4): 921-948.

Shacklock, K. \& Brunetto, Y. (2011). A model of older workers' intentions to continue working, Personnel Review, 40: 252-274. 
Shultz, K.S. and Wang, M. (2011) Psychological perspectives on the changing nature of retirement, American Psychologist, Apr, 66(3):170-9

Shultz, K.S., Wang, M., Crimmins, E. M., and Fisher, G.G. (2010). Age differences in the demand-control model of work stress: An examination of data from 15 European countries. Journal of Applied Gerontology, 29: 21-47.

StataCorp. 2019. Stata Statistical Software: Release 16. College Station, TX: StataCorp LLC.

Stone I (2011) International approaches to high performance working. London: UKCES

Stone I, Braidford P, Houston M. and Bolger F (2012) Promoting High Performance Working. London: BIS

Sun, L.-Y., Aryee, S., \& Law, K. S. (2007). High-performance human resource practices, citizenship behavior, and organizational performance: A relational perspective. Academy of Management Journal, 50(3), 558-577.

Taris, T. and Schreurs, P. (2009) Well-being and organizational performance: An organization-level test of the happy-productive worker hypothesis. Work \& Stress, 23(2):120-136.

Treadway DC, Ferris GR, Hochwater W, Perrewé P, Witt LA and Goodman JM (2005) The role of age in the perception of politics - job performance relationship: A three-study constructive replication, Journal of Applied Psychology 90(5): 872881.

Truxillo D, Cadiz D and Rineer J (2014) The aging workforce: Implications for human resource management research and practice, Oxford Handbooks Online, Oxford.

Truxillo DM and Fraccaroli F (2013), 'Research Themes on Age and Work: Introduction to the Special Issue,' European Journal of Work and Organizational Psychology, 22: 249-255.

UKCES (2009) Skills for the Workplace: Employer Perspectives, Evidence Report 1, November, UK Commission for Employment and Skills

UKCES (2014), The UK Commission's Employer Perspective Survey 2014: UK Results, UK Commission for Employment and Skills, London, UK.

Van Wanrooy B, Bewley H, Bryson A, Forth J, Freeth S, Stokes L and Wood S. (2013) Employment Relations in the Shadow of Recession: findings from the 2011 Workplace Employment Relations Study. London: Palgrave, Macmillan. 
Vickerstaff S, Phillipson C and Wilkie R (2012) Work Health and Wellbeing. Bristol: Policy Press.

Wainwright, D., Crawford, J., Loretto, W., Phillipson, C., Robinson, M., Shepherd, S., Vickerstaff, S. \& Weyman, A. (2019). Extending working life and the management of change. Is the workplace ready for the ageing worker? Ageing \& Society, 39: 2397-2419.

Warr P (1990) The measurement of well-being and other aspects of mental health, Journal of Occupational Psychology, 63: 193-210.

Warr P (2007) Work, happiness, and unhappiness. Mahwah, NJ: Lawrence Erlbaum.

Wood S and de Menezes LM (2011), 'High Involvement Management, High Performance Work Systems and Well-being', International Journal of Human Resource Management, 22(7): 1586-1610.

Wood SA, van Veldhoven M, Croon M and de Menezes LM (2012) Enriched job design, high involvement management and organizational performance: The mediating roles of job satisfaction and well-being, Human Relations, 65(4): 419445

Work Foundation (2005) People, strategy and performance: results from the second work and enterprise business survey. London: Department of Trade and Industry.

Wright PM and Gardner T M (2003) The human resource-firm performance in Holman, D., Wall, T., Clegg, C., Sparrow, P. \& Howard, A. (Eds.). The New Workplace A Guide to the Human Impact of Modern Working Practices, Ch 16: 311-330.

Wright TA and Hobfall SE (2004). Commitment, psychological well-being and job performance: an examination of conservation of resources (COR) theory, Journal of Business and Management 9 (4): 389-399.

Wright, P. M., Gardner, T. M., Moynihan, L. M., \& Allen, M. R. (2005). The relationship between HR practices and firm performance: Examining causal order. Personnel Psychology, 58(2), 409-446.

\section{Further reading}

Haile, G. and Smeaton, D. (2017), Are High Performance Work Practices compatible with the Extended Working Life agenda? WRW Working Paper No. 5, London, UK.

OECD (2013), OECD Employment Outlook 2013, OECD Publishing. 
Taris, T. and Schreurs, P. (2009), "Well-being and organizational performance: an organization-level test of the happy-productive worker hypothesis", Work and Stress, Vol. 23 No. 2, pp. 120-136.

Wainwright, D., Crawford, J., Loretto, W., Phillipson, C., Robinson, M., Shepherd, S., Vickerstaff, S. and Weyman, A. (2019), "Extending working life and the management of change. Is the workplace ready for the ageing worker?", Ageing and Society, Vol. 39, pp. 2397-2419. 
Table 1: Descriptive statistics for outcomes and key HPWS controls

\begin{tabular}{|c|c|c|c|c|}
\hline & $\begin{array}{l}\text { All } \\
(1)\end{array}$ & $\begin{array}{l}\text { Younger } \\
\text { (2) }\end{array}$ & $\begin{array}{l}\text { Older } \\
\text { (3) }\end{array}$ & $\begin{array}{l}\text { Difference } \\
(3-2)\end{array}$ \\
\hline \multicolumn{5}{|l|}{ Outcomes } \\
\hline Job Satisfaction & 4.7644 & 4.652 & 5.019 & $0.367^{\star \star \star}$ \\
\hline Well-being (anxiety) & 4.653 & 4.483 & 5.043 & $0.560^{* * *}$ \\
\hline \multicolumn{5}{|l|}{ HPWS bundles } \\
\hline \multicolumn{5}{|l|}{ Ability } \\
\hline Employee development & 1.900 & 1.888 & 1.927 & $0.039^{* * *}$ \\
\hline \multicolumn{5}{|l|}{ Motivation } \\
\hline Appraisal schemes & 2.261 & 2.296 & 2.183 & $-0.113^{\star \star \star}$ \\
\hline Flexible work & 3.374 & 3.347 & 3.435 & $0.088^{* * *}$ \\
\hline Incentive pay schemes & 0.666 & 0.701 & 0.585 & $-0.116^{\star \star \star}$ \\
\hline \multicolumn{5}{|l|}{ Opportunity } \\
\hline Autonomy & 1.341 & 1.347 & 1.329 & -0.018 \\
\hline Teamwork & 3.022 & 3.017 & 3.031 & 0.0135 \\
\hline Top-down communication & 2.614 & 2.608 & 2.626 & 0.0178 \\
\hline Employee engagement & 2.946 & 2.938 & 2.964 & $0.027^{*}$ \\
\hline No. of employees & 16,939 & 11,786 & 5,153 & \\
\hline No. of workplaces & 1,628 & & & \\
\hline
\end{tabular}


Table 2 - The AMO framework and corresponding survey questions considered

\begin{tabular}{|c|c|c|}
\hline AMO framework & $\begin{array}{l}\text { Related AMO } \\
\text { modules }\end{array}$ & Specific survey questions in each module \\
\hline $\begin{array}{l}\text { Ability } \\
\text { (Development } \\
\text { practices) }\end{array}$ & $\begin{array}{l}\text { Employee } \\
\text { development }\end{array}$ & $\begin{array}{l}\text { - whether employer is accredited as investor in } \\
\text { people } \\
\text { - whether workplace has formal strategic plan } \\
\text { covering employee development } \\
\text { - } 60 \% \text { + of staff had training in past year }\end{array}$ \\
\hline \multirow{3}{*}{$\begin{array}{l}\text { Motivation } \\
\text { (Policies to } \\
\text { influence } \\
\text { motivation and } \\
\text { effort) }\end{array}$} & Appraisal schemes & $\begin{array}{l}\text { - } 80 \%+\text { of employees have formal performance } \\
\text { appraisal } \\
\text { - } \text { performance appraisals consider training need } \\
\text { - } \text { pay is linked to performance appraisal }\end{array}$ \\
\hline & $\begin{array}{l}\text { Pay/incentive } \\
\text { scheme }\end{array}$ & $\begin{array}{l}\text { - if any employees get paid by merit } \\
\text { - if any employees get paid by results } \\
\text { - employees receive profit-related pay } \\
\text { - whether the company operates an employee share } \\
\text { scheme }\end{array}$ \\
\hline & Flexible working & $\begin{array}{l}\text { - workplace allows working from home } \\
\text { - employee has no set start/finish time } \\
\text { - ability to reduce working hours } \\
\text { - ability to work compressed hours } \\
\text { - employee can change set working hours } \\
\text { - employee can work only during school term time }\end{array}$ \\
\hline \multirow[t]{2}{*}{$\begin{array}{l}\text { Opportunity } \\
\text { (job autonomy, } \\
\text { communication, } \\
\text { engagement) }\end{array}$} & Teamwork & $\begin{array}{l}\text { - } \text { most }(60 \%+) \text { staff work in designated teams } \\
\text { - team members depend on each other's work to be } \\
\text { able to do their job } \\
\text { - team jointly decide how the work is to be done } \\
\text { - teams given responsibility for specific products or } \\
\text { services }\end{array}$ \\
\hline & Job autonomy & $\begin{array}{l}\text { - if [employees] perform jobs other than own? } \\
\text { - if [employees] have variety in their work? } \\
\text { - have discretion over how they do their work } \\
\text { - have control over their pace of work } \\
\text { - involved in decisions over how their work is } \\
\text { organised }\end{array}$ \\
\hline
\end{tabular}




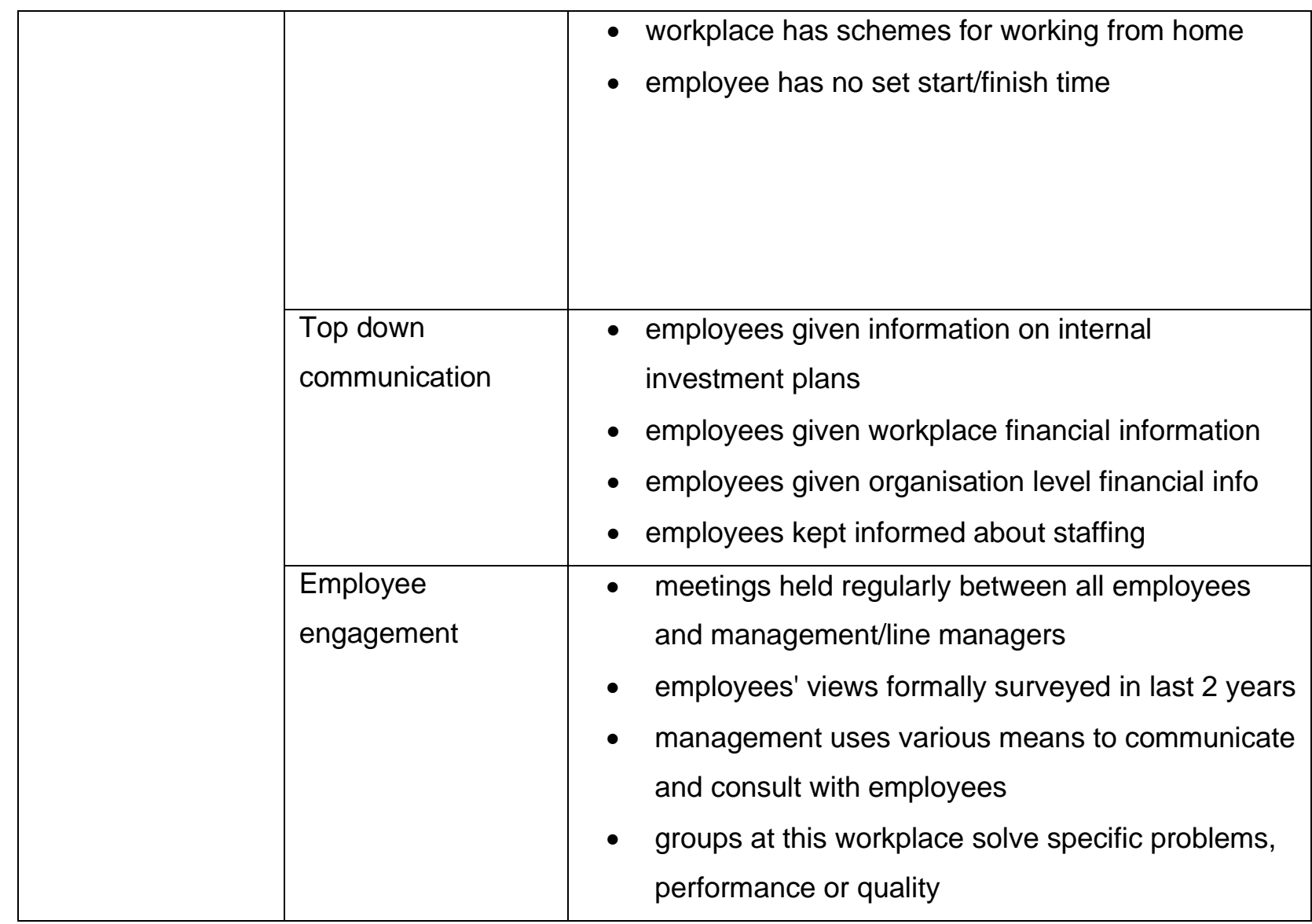


Table 3: Two-level estimation of Satisfaction and Well-being

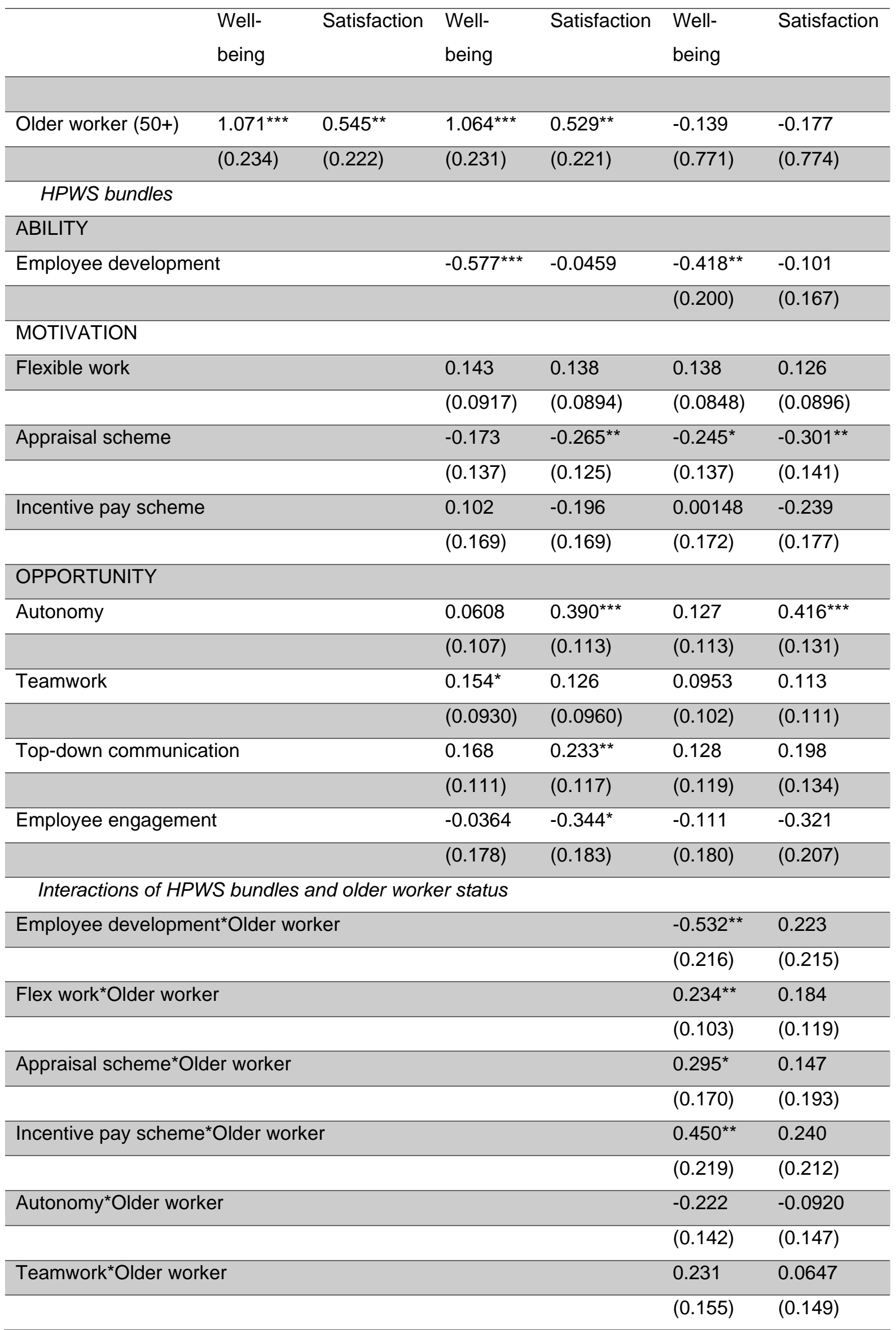




\begin{tabular}{|c|c|c|c|c|c|}
\hline \multicolumn{4}{|c|}{ Top-down communication*Older worker } & 0.132 & 0.135 \\
\hline & & & & $(0.161)$ & $(0.166)$ \\
\hline \multicolumn{4}{|c|}{ Employee engagement ${ }^{\star}$ Older worker } & 0.309 & -0.0871 \\
\hline & & & & $(0.256)$ & $(0.251)$ \\
\hline $\begin{array}{l}\text { Employee } \\
\text { characteristics }\end{array}$ & yes & Yes & yes & yes & yes \\
\hline $\begin{array}{l}\text { Workplace } \\
\text { characteristics }\end{array}$ & yes & Yes & yes & yes & yes \\
\hline
\end{tabular}

\begin{tabular}{|c|c|c|c|c|c|c|}
\hline \multicolumn{7}{|c|}{ Random-effects Parameters } \\
\hline \multirow[t]{2}{*}{$\sigma^{2}$ (Workplace) } & $0.717^{\star * *}$ & $0.810^{* * *}$ & $0.685^{\star * *}$ & $0.747^{* * *}$ & $0.688^{* * *}$ & $0.749^{* * *}$ \\
\hline & $(0.0771)$ & $(0.0647)$ & $(0.0750)$ & $(0.0705)$ & $(0.0756)$ & $(0.0701)$ \\
\hline \multirow[t]{2}{*}{$\sigma^{2}$ (error) } & $1.709^{* * *}$ & $1.698^{* * *}$ & $1.709^{\star \star *}$ & $1.698^{* \star *}$ & $1.706^{\star * *}$ & $1.697^{\star * *}$ \\
\hline & $(0.0148)$ & $(0.0123)$ & $(0.0147)$ & $(0.0123)$ & $(0.0147)$ & $(0.0122)$ \\
\hline Observations & 16,939 & 16,939 & 16,939 & 16,939 & 16,939 & 16,939 \\
\hline Number of groups & 1,628 & 1,628 & 1,628 & 1,628 & 1,628 & 1,628 \\
\hline
\end{tabular}

Robust standard errors in parentheses

${ }^{* * *} p<0.01,{ }^{* *} p<0.05,{ }^{*} p<0.1$

The estimation used employee and workplace weights 